\title{
Mechanical properties of composites with bioactive technology Giomer: a literature
}

\section{review}

\author{
Propriedades mecânicas dos compósitos com tecnologia bioativa Giomer: uma revisão de literatura \\ Propiedades mecánicas de los compósitos de tecnología bioactiva Giomer: una revisión de la
}

literatura

Received: 03/01/2021 | Reviewed: 03/06/2021 | Accept: 03/15/2021 | Published: 03/21/2021

\author{
André Rodrigo Justino da Silva \\ ORCID: https://orcid.org/0000-0002-9864-292X \\ Universidade de Pernambuco, Brazil \\ E-mail: andrerodonto@gmail.com \\ Vanessa Gonçalves Feitosa \\ ORCID: https://orcid.org/0000-0002-9984-2114 \\ Centro Odontológico de Estudos e Pesquisas, Brazil \\ E-mail: feitosavanessa@hotmail.com \\ Andressa Nascimento de Souza \\ ORCID: https://orcid.org/0000-0003-3307-4893 \\ Universidade Federal do Rio Grande do Norte, Brazil \\ E-mail: andressa.nasouza@gmail.com \\ Rafaela Pereira Deschamps Muniz \\ ORCID: https://orcid.org/0000-0001-9142-1705 \\ Universidade de Pernambuco, Brazil \\ E-mail: rafahmuniz99@gmail.com \\ Maria Clara Alves Sobral Ornellas \\ ORCID: https://orcid.org/0000-0003-1607-3098 \\ Universidade Federal de Campina Grande, Brazil \\ E-mail: a.aornellas@gmail.com \\ Elaine Patrícia Lima Silva \\ ORCID: https://orcid.org/0000-0003-1003-6632 \\ Instituto de Odontologia das Américas, Brazil \\ E-mail: elainepatricia9@gmail.com \\ Rodivan Braz \\ ORCID: https://orcid.org/0000-0003-3926-8736 \\ Universidade de Pernambuco, Brazil \\ E-mail: rodivan.braz@upe.br
}

\begin{abstract}
The objective is to evaluate the mechanical properties of the material bioactive restorative Giomer through an integrative literature review. The search was carried out in the months of July and August 2020 in the databases Pubmed and BVL, using two groups of descriptors connected by the boolean "AND" that allowed the inclusion of 20 articles in this review. The results show that the Giomer material showed laboratory flexural behavior superior to that compomer and glass ionomer cement, in addition to not reducing its flexural modulus when submerged in some substances. The microhardness of the Giomer suffered a reduction when in contact with acid solutions, such as refrigerant at based on Cola, coffee, citric acid and ethanol, in addition to undergoing changes according to photopolymerization protocol. It was possible to conclude that several factors can positively and negatively interfere with the mechanical properties of the Giomer composite when evaluated in vitro, as observed for acidic solutions and carbamide peroxide.
\end{abstract}

Keywords: Composite resins; Biocompatible materials; Mechanical phenomena.

\section{Resumo}

O objetivo é avaliar as propriedades mecânicas do material restaurador bioativo Giomer através de uma revisão integrativa da literatura. Realizou-se a busca nos meses de Julho e Agosto de 2020 nas bases de dados Pubmed e BVS, através do uso de dois grupos de descritores unidos pelo booleano "AND" que permitiram a inclusão de 20 artigos nessa revisão. Os resultados mostram que o material Giomer mostrou laboratorialmente comportamento flexural superior ao compômero e ao cimento de ionômero de vidro, além de não sofrer redução do seu módulo de flexão quando submerso em algumas substâncias. A microdureza do Giomer sofreu redução quando em contato com soluções ácidas, como refrigerante a base de Cola, café, ácido cítrico e etanol, além de sofrer alteração de acordo com o protocolo de fotopolimerização. Foi possível concluir que vários fatores podem interferir positivamente e 
negativamente nas propriedades mecânicas do compósito Giomer quando avaliados in vitro, como observado para soluções ácidas e peróxido de carbamida.

Palavras-chave: Resinas compostas; Materiais biocompatíveis; Fenômenos mecânicos.

\section{Resumen}

El objetivo es evaluar las propiedades mecánicas del material restaurador bioactivo Giomer a través de una revisión integradora de la literatura. La búsqueda se realizó en los meses de julio y agosto de 2020 en las bases de datos Pubmed y BVS, utilizando dos grupos de descriptores unidos por el booleano “AND” que permitió la inclusión de 20 artículos en esta revisión. Los resultados muestran que el material Giomer mostró, en laboratorio, un comportamiento de flexión superior al cemento de ionómero de vidrio y compómero, además de no sufrir una reducción de su módulo de flexión al sumergirse en algunas sustancias. La microdureza de Giomer se redujo al entrar en contacto con soluciones ácidas, como refrigerante a base de cola, café, ácido cítrico y etanol, además de sufrir cambios según el protocolo de fotopolimerización. Fue posible concluir que varios factores pueden interferir positiva y negativamente en las propiedades mecánicas del compuesto de Giomer cuando se evalúa in vitro, como se observó para las soluciones ácidas y el peróxido de carbamida.

Palabras clave: Resinas compuestas; Materiales biocompatibles; Fenómenos mecánicos.

\section{Introduction}

The increased clinical applicability of resinous materials has generated evolution and improvement of its properties, in order to guarantee greater predictability and longevity of restorations. Since the introduction of composite resins in the market, the industry seeks to improve the physical properties and mechanics by modifying some component of the material to make it so more stable (Ergucu \& Turkun, 2007; Ferracane, 2011; Soares et al., 2019).

One of the most important innovations that occurred in recent years was the incorporation of nanometric-sized charge particles, giving rise to nano-hybrid and nanoparticulate composites. This particle size allows the increase in volume of inorganic content improving resistance to flexion, traction and compression of the material (Ozak \& Ozkan, 2013; Silva, Poskus, Guimaraes, 2008; Van DÊken, 2000; Van Nieuwenhuysen et al., 2003).

As the development of research in the dental materials area is in progress constant evolution, materials with bioactive properties were added to the market. These composites behave as an alternative to traditional composites without bioactive potential and glass ionomer cements, which despite the release of fluoride ions have aesthetic impairment and low physical properties (Bayrak et al., 2010; McCabe et al., 2011). Among these materials considered to be intelligent behavior is the group of Giomer light-cured resin composites, which employ glass particles with pre-reacted surface (S-PRG), as components of the inorganic filler. These particles release various ions like fluoride in the presence of acids and water, assisting the biodynamic balance of teeth and saliva and acting on maintenance of oral health (Yu, Yap, Wang, 2017).

However, the mechanical properties of this material can be compromised when subjected to high stress areas. Fractures in the body and margins of the restorations can lead to failure of the giomer composite. Knowing that the properties mechanics of fracture toughness and flexural strength are important criteria for the longevity of any dental material (Garoushi, Vallittu, Lassila, 2018), the guiding question of this study was: what factors can interfere in the mechanical properties of the giomer composites? Therefore, the objective of this integrative review was to assess mechanical properties of Giomer bioactive restorative materials.

\section{Methodology}

This is a integrative review, a secondary study developed to gather the main findings on the mechanical properties of Giomer composites (Pereira et al., 2018). In order to achieve the objective of the study, during the months of July and August 2020 the search for scientific articles was carried out in the databases Pubmed and BVS (Biblioteca Virtual em Saúde). The research strategy was based initially using two groups of descriptors united by the boolean "OR": group \#1 composed by “beautifil restorative”, "beautifil composite resin”, “giomer”; grupo \#2 composed by "hardness”, "hardness test”, “compressive 
strenght", "flexural strenght", "flexural resistance". Then the results of group \#1 were connected and filtered with those of group \#2 through a new search using the boolean "AND".

The inclusion criteria used were: scientific articles published among the years 2010 and 2020; studies with in vitro development methodology; studies published in the English language; studies that evaluate the mechanical properties of Giomer restorative materials. The established exclusion criteria were: thesis; dissertations; articles published before 2010; articles not available in whole; literature review articles.

\section{Results}

After searching the databases, 29 articles were found in Pubmed and 37 in the BVS, totaling 66 articles. After reading the title and summary of these studies the inclusion criteria were applied, thus leaving 48 studies. Of these, after reading in full, 28 duplicate studies were removed and that contemplated the established exclusion criteria, thus ending the selection with the 20 articles used in the integrative review. Selected studies are characterized in Table 1 by the authors, year of publication, mechanical tests made and Giomers materials used.

Table 1. Description of the selected studies regarding the authors, year of publication, mechanical tests performed and material used.

\begin{tabular}{|c|c|c|c|}
\hline Authors & Year & Mechanical tests performed & Giomer tested \\
\hline Ugurlu et al. & 2020 & 3-point bending test & $\begin{array}{l}\text { Beautifil II (Shofu Co. Kyoto, } \\
\text { Japan) }\end{array}$ \\
\hline$\underline{\text { Parasher }}$ et al. & 2020 & Vickers microhardness & $\begin{array}{l}\text { Beautifil Bulk restorative (Shofu } \\
\text { Co. Kyoto, Japan) }\end{array}$ \\
\hline Eweis et al. & 2020 & $\begin{array}{l}\text { 3-point bending test, miniflexural and flexural } \\
\text { modulus test }\end{array}$ & $\begin{array}{c}\text { Beautifil II; } \\
\text { Beautifil Bulk restorative; } \\
\text { Beautifil Bulk flowable (Shofu } \\
\text { Co. Kyoto, Japan) }\end{array}$ \\
\hline Spajic et al. & 2019 & Vickers microhardness & $\begin{array}{l}\text { Beautifil II (Shofu Co. Kyoto, } \\
\text { Japan) }\end{array}$ \\
\hline Choi et al. & 2019 & Vickers microhardness & $\begin{array}{l}\text { Beautifil II (Shofu Co. Kyoto, } \\
\text { Japan) }\end{array}$ \\
\hline Silva et al. & 2019 & Knoop microhardness & $\begin{array}{l}\text { Beautifil II (Shofu Co. Kyoto, } \\
\text { Japan) }\end{array}$ \\
\hline Garoushi et al. & 2018 & 3-point bending test and Vickers microhardness & $\begin{array}{l}\text { Beautifil II (Shofu Co. Kyoto, } \\
\text { Japan) }\end{array}$ \\
\hline Kaya et al. & 2018 & Vickers microhardness & $\begin{array}{l}\text { Beautifil Bulk restorative (Shofu } \\
\text { Co. Kyoto, Japan) }\end{array}$ \\
\hline Yap et al. & 2018 & $\begin{array}{l}\text { 3-point dynamic and static flexion and flexural } \\
\text { strength tests }\end{array}$ & $\begin{array}{l}\text { Beautifil Bulk restorative (Shofu } \\
\text { Co. Kyoto, Japan) }\end{array}$ \\
\hline Zhou et al. & 2018 & $\begin{array}{c}\text { 3-point bending test, flexural strength and modulus } \\
\text { of elasticity }\end{array}$ & $\begin{array}{l}\text { Beautifil flow plus (Shofu Co. } \\
\text { Kyoto, Japan) }\end{array}$ \\
\hline Eweis et al. & 2018 & 3-point bending test & $\begin{array}{l}\text { Beautifil Bulk restorative (Shofu } \\
\text { Co. Kyoto, Japan) }\end{array}$ \\
\hline Tsujimoto et al. & 2017 & 3-point bending test and flexural strength & $\begin{array}{c}\text { Beautifil Bulk restorative; } \\
\text { Beautifil Bulk flow (Shofu Co. } \\
\text { Kyoto, Japan) }\end{array}$ \\
\hline
\end{tabular}




\begin{tabular}{|c|c|c|c|}
\hline Kimyai et al. & 2017 & Vickers microhardness & $\begin{array}{l}\text { Beautifil II (Shofu Co. Kyoto, } \\
\text { Japan) }\end{array}$ \\
\hline $\begin{array}{c}\text { Ilie \& } \\
\text { Stawarczyk }\end{array}$ & 2016 & Vickers microhardness and indentation modulus & $\begin{array}{c}\text { Beautifil Bulk restorative (Shofu } \\
\text { Co. Kyoto, Japan) }\end{array}$ \\
\hline Gonulol et al. & 2016 & Vickers microhardness & $\begin{array}{c}\text { Beautifil II (Shofu Co. Kyoto, } \\
\text { Japan) }\end{array}$ \\
\hline Ilie \& Fleming & 2015 & Vickers microhardness and indentation modulus & $\begin{array}{l}\text { Beautifil Bulk restorative; } \\
\text { Beautifil Bulk flow (Shofu Co. } \\
\text { Kyoto, Japan) }\end{array}$ \\
\hline Tanthanuch et al. & 2014 & Vickers microhardness & $\begin{array}{l}\text { Beautifil II (Shofu Co. Kyoto, } \\
\text { Japan) }\end{array}$ \\
\hline Kooi et al. & 2012 & Knoop microhardness & $\begin{array}{c}\text { Beautifil II; Beautifil Bulk flow } \\
\text { plus (Shofu Co. Kyoto, Japan) }\end{array}$ \\
\hline Naoum et al. & 2011 & Berkovich hardness test & $\begin{array}{l}\text { Beautifil II (Shofu Co. Kyoto, } \\
\text { Japan) }\end{array}$ \\
\hline $\begin{array}{c}\text { Lien \& } \\
\text { Vandewalle }\end{array}$ & 2010 & $\begin{array}{l}\text { Tests of resistance to diametrical traction, } \\
\text { compression force, resistance and flexural modulus, } \\
\text { fracture resistance and Knoop microhardness }\end{array}$ & $\begin{array}{c}\text { Beautifil II (Shofu Co. Kyoto, } \\
\text { Japan) }\end{array}$ \\
\hline
\end{tabular}

Source: Authors.

\section{Flexural properties:}

The effect of ionizing radiation from X-rays with high energy does not seem to interfere with the flexural properties of restorative materials, especially for the giomer that has shown a higher flexural strength value when compared to glass ionomer cements and a carbomer. In addition, the flexural strength was not influenced by the surface roughness of the materials (Ugurlu, Ozkan, Ozseven, 2020). When subjected to dry and wet conditions, the material presented a flexural strength value superior to that of other bioactive resin, to the ionomer modified by resin and to compomers, being considered the most stable material among those studied (Garoushi, Vallittu, Lassila, 2018). When compared to a compomer and three composites (nanoparticulate, hybrid and micro-hybrid) the giomer presented with the highest flexural modulus value (Lien \& Vanderwalle, 2010).

When comparing three different giomer viscosities, it was observed that the high viscosity bulk-fill showed the highest flexural modulus when stored in ethanol, artificial saliva and air. When stored in citric acid, the conventional giomer demonstrated the greatest flexion modulus (Eweis, Yap, Yahya, 2020).

When testing the effect of aqueous solutions on the reduction of strength and flexural modulus of various bulk-fill materials, it was observed that all of these suffered a reduction, especially in contact with artificial saliva (Eweis, Yap, Yahya, 2018). After aging by water and salivary microorganisms, the giomer significantly reduced its resistance to flexion, but with an elastic modulus higher than that observed before aging. In addition, for aging performed with Streptococcus mutans, the giomer showed positive and superior characteristics to the glass ionomer cement tested (Zhou et al., 2018).

Comparing low and high viscosity bulk-fill materials, it was found that the giomers showed positive flexural strength and modulus values, comparable to conventional bulk-fill composites, regardless of the polymerization time employed (Tsujimoto et al., 2017).

An interesting finding was observed in one study (Yap, Eweis, Yahya, 2018) who found that samples with dimensions of $25 \times 2 \times 2 \mathrm{~mm}$ showed superior static and dynamic flexural properties when compared to dimensions $12 \times 2 \times 2 \mathrm{~mm}$, providing important information for future in vitro studies using a 3-point flexion test. 


\section{Microhardness:}

The Vickers microhardness of the bulk-fill giomer was superior when compared to the Tetric EvoCeram bulk fill (Ivoclar/Vivadent AG, Schaan, Liechtenstein), but it presented a low polymerization depth value (Parasher et al., 2020). In addition, the giomer showed Knoop values higher than that obtained for silorane, as well as for the micro-hybrid composite and compomer (Lien \& Vandewalle, 2010).

Extremely relevant information was verified in the studies by Choi et al. (2019) and Tanthanuch et al. (2014) who observed that the submersion of the giomer in Cola-based soft drink brought a significant rate of reduction in the hardness of the material. In addition, the study by Silva et al. (2019) achieved significant reduction in the microhardness of the material with its immersion in coffee associated with the brushing simulation, as well as with its immersion in artificial saliva, showing that the Knoop microhardness of the giomer was inferior to that observed by the nanoparticulate composite. Another study verified this reduction when the material was put in contact with citric acid and ethanol (Kooi et al., 2012).

On the other hand, no significant change in the hardness of the material was observed when submitted to three months of aging in acidic solution of $\mathrm{pH}$ 4.0. However, after the same time in water, the material showed an increase in the modulus of elasticity (Naoum et al., 2011). The storage for one year in distilled water was related to the improvement of the mechanical properties of the restoration, so that the dentin-giomer interface at the bottom of the preparation maintained its favorable mechanical characteristics during the study period (Ilie \& Stawarczyk, 2016).

Comparing the degree of polymerization of the bulk-fill giomer submitted to three different photopolymerization units, it was possible to associate the third generation Polywave Valo (Ultradent, South Jordan, USA) with the lowest microhardness of the giomer among the units tested. In addition, the polymerization protocol influenced the mechanical performance of the material, thus concluding that the polymerization time may influence the compression strength of the giomer more than the power of the device (Kaya et al., 2018). In addition, another study found that Valo's "extra Power" polymerization mode (Ultradent, South Jordan, USA) resulted in lower Vickers microhardness values in the material samples (Gonulol, Ozer, Tunc, 2016).

It has been seen that high and low viscosity bulk-fill giomers keep their mechanical properties at a clinically acceptable level when polymerized at a thickness of $4 \mathrm{~mm}$. In addition, they behaved mechanically in a superior way to the conventional bulk fill composites tested (Ilie \& Fleming, 2015). The hardness values were twice as high for the giomer when compared to self-curing and light-curing glass ionomer cements. In addition, it was found that the light curing power of 1,100 $\mathrm{mW} / \mathrm{cm} 2$ proved to be the most efficient for improving the microhardness of all the materials studied (Spajic et al., 2019).

By evaluating bleaching techniques, it was possible to obtain a relationship between contact with carbamide peroxide and the reduction of the material's microhardness, so that the higher the concentration of the peroxide, the greater the reduction observed (Kimyai et al., 2017).

\section{Discussion}

The variables that can be used to measure the mechanical properties of giomers are diverse, as verified in the studies included in this review. The giomer material is shown to be laboratory superior to some other materials such as compomer and glass ionomer cement, especially when observing its flexural behavior. In addition, the immersion of this material in some substances does not seem to negatively interfere with its flexion modulus (Garoushi, Vallittu, Lassila, 2018; Eweis, Yap, Yahya, 2020; Zhou et al., 2018).

Regarding microhardness, the use of the Vickers microhardness technique was predominant in the in vitro studies observed, due to its accuracy for the methodologies used (Garoushi, Vallittu, Lassila, 2018; Parasher et al., 2020; Spajic et al., 2019; Choi et al., 2019; Kaya et al., 2018; Kimyai et al., 2017; Ilie \& Stawarczyk, 2016; Gonulol, Ozer, Tunc, 2016; Ilie e 
Fleming, 2015; Tanthauch et al., 2014). Instead to what was observed for flexural properties, in some studies the material suffered a reduction in microhardness when submerged in some solutions (Choi et al., 2019; Silva et al., 2019; Tanthanuch et al., 2014; Kooi et al., 2012). In addition, the polymerization protocol influenced the microhardness of the giomer, as well as the supervised whitening at home protocol (Kaya et al., 2018; Kimyai et al., 2017; Gonulol, Ozer, Tunc, 2016).

The flexural strength of a material consists of the maximum flexural charge capable of stressing it before failure, so for restorations in the posterior region, especially Class I and Class II, the test requires a minimum flexural strength value of 80 MPa for dental polymeric materials (Heintze et al., 2017).

The changes that occur when a resinous material is submerged in water are justified by the hydrolytic degradation on the silane, which leads to the weakening of the resinous matrix due to water sorption and dissolution of the material components. This causes the displacement of particles from its external surface, leading to increased surface roughness and decreased hardness (Boaro et al., 2013; Toledano et al., 2003; Santos et al., 2002; EL-Sharkawy, Zaghloul, Ell-Kapanney, 2012). However, in the case of a giomer material there is a stability of properties due to the pre-reacted surface glass particles (S-PRG), which protect the material from the damaging effects of moisture. This occurs due to the acid-base reaction that is carried out on S-PRG charges even during manufacture (Ilie \& Stawarczyk, 2016; Roberts et al, 1999). This justifies the findings of improvement in some mechanical properties of this material seen in studies present in this review, even after long contact with water.

Adequate polymerization of the composite resin is achieved through a uniform distribution of the energy emitted to all layers of the material, allowing the formation of a sufficient number of free radicals (Michaud et al., 2014). When it comes to the size and volume of the charge particles, they relate to the rate of wear and resistance, so that the greater the volume of charge the lower the rate of wear. This happens due to the smaller extent of resin unprotected by the load (Tanthanuch et al., 2014; Condor \& Ferracane, 1997).

The acidic $\mathrm{pH}$ of the substances can induce erosive wear thanks to the dissolution of the resin matrix. This process causes the matrix to soften and promotes displacement and leaching of the charge particles (Coombes, 2005; Erdemir et al., 2012). For this reason, in addition to the cola-based drink having a low measurable acidity, it is a carbonated drink that contains phosphoric acid and therefore, together with alcohol, were able to reduce microhardness in the studies evaluated (Choi et al., 2019; Tanthanuch et al., 2014; Kooi et al., 2012; Bagheri, Tyas, Burrow, 2007).

As observed in the results of the present study, the bleaching agents seem to interfere with resins, impairing their mechanical properties, with a greater amplitude for those with a greater volume of organic matrix. These agents can affect both the resin matrix and the bonding interface, but do not affect the filler particles. The mechanism that justifies this relationship is the disruption of double bonds and the separation of polymeric chains from the material through the production of free radicals that affect the existing interface between resin matrix and filler particles, which can create micro cracks that reduce microhardness. This process is amplified the higher the concentration of peroxide (Briso et al., 2010; Campos et al., 2003).

The limitations of this integrative review were based on the small number of studies available for inclusion in this review, as it is a relatively recent restorative material. In addition, it is not possible to faithfully extrapolate the information obtained in this article into clinical practice, so that further studies involving the use of Giomer technology are necessary. Therefore, it is suggested to carry out new clinical trials that monitor the behavior of restorations performed with giomer restorative materials, especially assessing their anticariogenic function.

\section{Conclusion}

Thus, it was noted that several factors can interfere in the mechanical properties of restorative materials with Giomer technology, both positively and negatively, when evaluated in vitro. More specifically, the flexural properties seem to be 
affected by the contact of the material with artificial saliva and water, while the microhardness was reduced when in contact with acidic solutions and carbamide peroxide.

This integrative review is expected to provide support to guide future in vitro studies involving bioactive restorative materials, especially those focusing on the study of the mechanical behavior of these products. New studies that evaluate other properties of this material are recommended, such as color characteristics, for example, both with in vitro methodology and randomized clinical trials with a follow-up time.

\section{References}

Bagheri, R., Tyas, M. J., Burrow, M. F. (2007). Subsurface degradation of resin-based composites. Dent Mater, 23, 944-951. https://doi.org/10.1016/j.dental.2006.06.035

Bayrak, S., Tunc, E. S., Aksoy, A., Ertas, E., Guvenc, D., Ozer, S. (2010). Fluoride release and recharge from different materials used as fissure sealants. Eur J Dent, 4, 245-250.

Boaro, L. C., Gonçalves, F., Guimarães, T. C., Ferracane, J. L., Pfeifer, C. S., Braga, R. R. (2013). Sorption, solubility, shrinkage and mechanical properties of "low-shrinkage" commercial resin composites. Dent Mater, 29, 398-404. https://doi.org/10.1016/j.dental.2013.01.006

Briso, A. L., Tuñas, I.T., de Almeida, L. C., Rahal, V., Ambrosano, G. M. (2010). Effects of five carbamide peroxide bleaching gels on composite resin microhardness. Acta Odontol Latinoam, 23, 27-31.

Campos, I., Briso, A. L., Pimenta, L. A., Ambrosano, G. (2003). Effects of bleaching with carbamide peroxide gels on microhardness of restoration materials. J Esthet Restor Dent, 15, 175-82. https://doi.org/10.1111/j.1708-8240.2003.tb00187.x

Choi, J. W., Lee, M. J., Oh, S. H., Kim, K. M. (2019). Changes in the physical properties and color stability of aesthetic restorative materials caused by various beverages. Dent Mater J, 38(1), 33-40.

Condon, J. R., Ferracane, J. (1997). In vitro wear of composite with varied cure, filler level, and filler treatment. J Dent Res, 76, 1405-1411. https://doi.org/10.1177\%2F00220345970760071101

Coombes, J. S. (2005) Sports drinks and dental erosion. Am J Dent, 18, 101-104.

EL-Sharkawy, F. M., Zaghloul, N. M., Ell-kappaney, A. M. (2012). Effect of water absorption on color stability of different resin based restorative materials in vitro study. Int J Compos Mater, 2, 7-10.

Erdemir, U., Yildiz, E., Eren, M. M., Ozel, S. (2012). Surface hardness of different restorative materials after long-term immersion in sports and energy drinks. Dent Mater J, 31, 729-736. https://doi.org/10.4012/dmj.2012-054

Ergucu, Z., Turkun, L. S. (2007). Clinical performance of novel resin composites in posterior teeth: 18-month results. J Adhes Dent, 9, $209-216$.

Eweis, A. H., Yap, A. U., Yahya, N. A. (2018). Impact of dietary solvents on flexural properties of bulk-fill composites. Saudi Dent J, 30, 232-239. https://doi.org/10.1016/j.sdentj.2018.04.002

Eweis, A. H., Yap, A. U., Yahya, N. A. (2020). Comparison of Flexural Properties of Bulk-fill Restorative/Flowable Composites and Their Conventional Counterparts. Oper Dent, 45, 41-51. https://doi.org/10.2341/18-133-L

Ferracane, J. L. (2011). Resin composite--state of the art. Dent Mater, 27, 29-38. https://doi.org/10.1016/j.dental.2010.10.020

Garoushi, S., Vallittu, P. K., Lassila, L. (2018). Characterization of fluoride releasing restorative dental materials. Dent Mater J, 37, $293-300$.

Gonulol, N., Ozer, S., Tunc, E. S. (2016). Effect of a third-generation LED LCU on microhardness of tooth-colored restorative materials. Int J Paediatr Dent, 26, 376-382. https://doi.org/10.1111/ipd.12213

Heintze, S. D., Ilie, N., Hickel, R., Reis, A., Loguercio, A., Rousson, V. (2017). Laboratory mechanical parameters of composite resins and their relation to fractures and wear in clinical trials - A systematic review. Dent Mater, 33, 101-114. https://doi.org/10.1016/j.dental.2016.11.013

Ilie, N., Fleming, G. J. (2015). In vitro comparison of polymerisation kinetics and the micro-mechanical properties of low and high viscosity giomers and RBC materials. J Dent, 43, 814-822. https://doi.org/10.1016/j.jdent.2015.04.009

Ilie, N., Stawarczyk, B. (2016). Evaluation of modern bioactive restoratives for bulk-fill placement. $J$ Dent, 49, 46-53. https://doi.org/10.1016/j.jdent.2016.04.001

Kaya, M. S., Bakkal, M., Durmus, A., Durmus, Z. (2018). Structural and mechanical properties of a giomer-based bulk fill restorative in different curing conditions. J Appl Oral Sci, 26, e20160662. https://doi.org/10.1590/1678-7757-2016-0662

Kimyai, S., Bahari, M., Naser-Alavi, F., Behboodi, S. (2017). Effect of two different tooth bleaching techniques on microhardness of giomer. J Clin Exp Dent, 9, 249-253. http://dx.doi.org/10.4317/jced.53290

Kooi, T. J., Tan, Q. Z., Yap, A. U., Guo, W., Tay, K. J., Soh, M. S. (2012). Effects of food-simulating liquids on surface properties of giomer restoratives. Oper Dent, 37, 665-671. https://doi.org/10.2341/11-419-L 
Lien, W., Vandewalle, K. S. (2010). Physical properties of a new silorane-based restorative system. Dent Mater, 26, 337-344. https://doi.org/10.1016/j.dental.2009.12.004

McCabe, J. F., Yan, Z., Al Naimi, O. T., Mahmoud, G., Rolland, S. L. (2011). Smart materials in dentistry. Aust Dent J, 56(1), 3-10. https://doi.org/10.1111/j.1834-7819.2010.01291.x

Michaud, P. L., Price, R. B., Labrie, D., Rueggeberg, F. A., Sullivan, B. (2014). Localised irradiance distribution found in dental light curing units. J Dent, 42, 129-139. https://doi.org/10.1016/j.jdent.2013.11.014

Naoum, S., Ellakwa, A., Martin, F., Swain, M. (2011). Fluoride release, recharge and mechanical property stability of various fluoride-containing resin composites. Oper Dent, 36, 422-432. https://doi.org/10.2341/10-414-L

Ozak, S. T., Ozkan, P. (2013). Nanotechnology and dentistry. Eur J Dent, 7(1), 7.

Parasher, A., Ginjupalli, K., Somayaji, K., Kabbinale, P. (2020). Comparative evaluation of the depth of cure and surface roughness of bulk-fill composites: An in vitro study. Dent Med Probl, 57, 39-44. https://doi.org/10.17219/dmp/113003

Pereira A.S., Shitsuka, D. M., Parreira, F. J., Shitsuka, R. (2018). Metodologia da pesquisa científica. UFSM.

Roberts, T., Miyai, K., Ikemura, K., Fuchigami, K., Kitamura, T. (1999). Fluoride ion sustained release preformed glass ionomer filler and dental compositions containing the same. United States Patent, 5, 883-153.

Santos, C., Clarke, R. L., Braden, M., Guitian, F., Davy, K. W. (2002). Water absorption characteristics of dental composites incorporating hydroxyapatite filler. Biomaterials, 23, 1897-1904. https://doi.org/10.1016/S0142-9612(01)00331-3

Silva, E. M., Poskus, L. T., Guimaraes, J. G. (2008). Influence of light-polymerization modes on the degree of conversion and mechanical properties of resin composites: a com-parative analysis between a hybrid and a nanofilled composite. Oper Dent, 33, 287-293. https://doi.org/10.2341/07-81

Silva, T. M., Dantas, D. C. B., Franco, T. T., Franco, L. T., Huhtala, M. F. R. L. (2019). Surface degradation of composite resins under staining and brushing challenges. J Dent Sci, 14, 87-92. https://doi.org/10.1016/j.jds.2018.11.005

Soares, P. V., Peres, T. S., Wobido, A. R., Machado, A. C. (2019). Composite resin in the last 10 years - Literature Review. Part 1: Chemical composition. J Clin Dent Res, 16, 45-56.

Spajic, J., Par, M., Milat, O., Demoli, N., Bjelovucic, R., Prskalo, K. (2019). Effects of Curing Modes on the Microhardness of Resin-modified Glass Ionomer Cements. Acta Stomatol Croat, 53, 37-46. https://doi.org/10.15644/asc53/1/4

Tanthanuch, S., Kukiattrakoon, B., Siriporananon, C., Ornprasert, N., Mettasitthikorn, W., Likhitpreeda, S., et al. (2014). The effect of different beverages on surface hardness of nanohybrid resin composite and giomer. J Conserv Dent, 17, 261-265. https://www.jcd.org.in/text.asp?2014/17/3/261/131791

Toledano, M., Osorio, R., Osorio, E., Prati, C., Garcia Godoy, F. (2003). Sorption and solubility of resin based restorative dental materials. J Dent, 31, 43-50. https://doi.org/10.1016/S0300-5712(02)00083-0

Tsujimoto, A., Barkmeier, W. W., Takamizawa, T., Latta, M. A., Miyazaki, M. (2017). Depth of cure, flexural properties and volumetric shrinkage of low and high viscosity bulk-fill giomers and resin composites. Dent Mater J, 36, 205-213. https://doi.org/10.4012/dmj.2016-131

Ugurlu, M., Ozkan, E. E., Ozseven, A. (2020). The effect of ionizing radiation on properties of fluoride-releasing restorative materials. Braz Oral Res, 34, e005. https://doi.org/10.1590/1807-3107bor-2020.vol34.0005

van DÊken, J. W. (2000). Direct resin composite inlays/onlays: an 11 year follow-up. J Dent, 28, 299-306. https://doi.org/10.1016/S0300-5712(00)00010-5

Van Nieuwenhuysen, J. P., D’Hoore, W., Carvalho, J., Qvist, V. (2003). Long-term evaluation of extensive restorations in permanent teeth. J Dent, 31, 395405. https://doi.org/10.1016/S0300-5712(03)00084-8

Yap, A. U., Eweis, A. H., Yahya, N. A. (2018). Dynamic and Static Flexural Appraisal of Resin-based Composites: Comparison of the ISO and Mini-flexural Tests. Oper Dent, 43, 223-231. https://doi.org/10.2341/17-224-L

Yu, P., Yap, A. U. J., Wang, X. Y. (2017). Degree of Convention and Polymerization Shrinkage of bulk-fill resin -based composite. Oper Dent, 42 , 82-89.

Zhou, X., Wang, S., Peng, X., Hu, Y., Ren, B., Li, M., et al. (2018). Effects of water and microbial-based aging on the performance of three dental restorative materials. J Mech Behav Biomed Mater, 80, 42-50. https://doi.org/10.1016/j.jmbbm.2018.01.023 